\title{
Antara Pengrajin dan Desainer
}

\author{
P. Gogor Bangsa \\ Desain Komunikasi Visual, Fakultas Seni Rupa, \\ Institut Seni Indonesia, Yogyakarta, Indonesia \\ E-mail: gogorbangsa@gmail.com
}

\begin{abstract}
Abstrak
Dunia desain mengenal beberapa metode desain dalam proses penciptaan karya desain. Metode-metode desain tersebut menjadi acuan cara kerja bagi para desainer. Sebagai contoh pembahasan adalah dalam penciptaan logo yang dilakukan oleh para desainer grafis otodidak di kecamatan Salaman, Magelang, desainer grafis profesional dan korporasi desain grafis dan dalam ranah akademik. Sebagai contoh kasus untuk perbandingan metode tersebut adalah fenomena kontes desain online dan pengerjaan logo dalam branding perusahaan multinasional oleh korporasi desain grafis.
\end{abstract}

Kata kunci: Metode desain, desain grafis, desainer grafis.

\begin{abstract}
The world of design recognize some methods of design in the design process. These methods such a reference of how to work for designers. For example, the discussion is the creation of a logo between the self-taught graphic designer in the district Salaman, Magelang; professional graphic designers and graphic design firm; and in the academic sphere. As an example the case for the comparison of these methods is the phenomenon of online design contest and logo making in multinational corporation branding by a graphic design firm.
\end{abstract}

Keywords: Methods of design, graphic design, graphic designer.

\section{Pendahuluan}

Pada dunia desain dikenal beberapa metode desain yang diterapkan dalam proses pembuatan desain. Penerapan tersebut sudah dilakukan oleh kalangan desainer grafis profesional atau korporasi desain grafis dan di lingkungan akademis. Salah satu produk dari desain grafis adalah logo. Logo sendiri merupakan bagian dari corporate identity, sedangkan corporate identity merupakan bagian dari sebuah brand. Dalam merancang logo, para desainer grafis profesional memakai metode yang runtut dan kompleks. Namun dalam 5 tahun terakhir muncul fenomena kontes desain online yang memiliki prosedur lebih singkat dengan imbalan instan dibanding yang dilakukan oleh para professional.

\section{Situs Kontes Desain Grafis Online 99designs.com}

99designs (99designs.com) adalah sebuah situs pasar desain grafis online, yang mempertemukan antara desainer dan pihak yang membutuhkan layanan jasa desain. Cara kerja perusahaan ini cukup sederhana, yaitu menciptakan produk mereka dengan cara crowdsourcing, yang mana pelanggan dapat mengajak para desainer untuk mengirimkan desain mereka untuk kontes menciptakan desain untuk berbagai keperluan desain grafis seperti website, t-shirt atau logo. Kemudian pelanggan akan memilih desain yang terbaik dari desain yang masuk dan desainer yang menang akan mendapatkan pembayaran secara tunai.

Istilah crowdsourcing sendiri muncul pada tahun 2005 sebagai sebuah istilah di dunia bisnis modern yang didefinisikan sebagai sebuah proses memperoleh layanan atau jasa yang dibutuhkan dengan cara meminta kontribusi dari masyarakat luas khususnya dari komunitas dunia maya (online), bukan lagi dengan cara tradisional seperti dalam sebuah perusahaan (yang menggunakan karyawan atau supplier).

Didirikan oleh Mark Harbottle dan Matt Mickiewicz di Melbourne, Australia pada tahun 2008, yang kemudian pada tahun 2010 mendirikan kantor di Amerika Serikat (http://www.entrepreneurs-journey.com/2873/matt-mickiewicz/diakses 27 September 2015). 99design memiliki visi untuk masa depan yaitu menantang status quo 
dari proses desain yang tradisional dan mempromosikan sebuah hubungan yang kuat antara desainer dengan perusahaan-perusahaan kecil. Hingga nanti tahun 2016 mereka memproyeksikan akan membantu lebih dari satu juta orang untuk mengembangkan bisnis mereka melalui desain yang berkualitas tinggi namun dengan biaya yang terjangkau (http://99designs.com/about, akses 27 September 2015).

Hingga saat ini, sistem kerja seperti yang ditawarkan oleh 99designs telah menjadi alternatif untuk mendapatkan pekerjaan desain di kalangan desainer grafis freelance hampir di seluruh dunia. Kategori desain yang ditawarkan juga beragam misalnya: desain logo dan identitas, desain web dan aplikasi, desain iklan, desain untuk t-shirt dan merchandise, ilustrasi, desain label dan kemasan, desain buku dan majalah dan sebagainya. Bayaran yang diberikan bervariasi kurang lebih antara US\$40 untuk sebuah pekerjaan sederhana seperti desain banner iklan untuk tampilan halaman media sosial misalnya, hingga US\$1,655 untuk sebuah tampilan website. Atau desain logo perusahaan yang dihargai antara US\$135 hingga US $\$ 925$.

Barangkali angka bayaran tersebut terbilang kecil untuk level desainer grafis profesional, atau bahkan terhitung sangat kecil bagi korporasi desain grafis, namun tidak begitu bagi para desainer grafis freelance atau pemula. Sehingga dengan jumlah bayaran yang diterima dan relatif mudahnya prosedur mendapatkan dan mengerjakan job desain menjadi daya tarik tersendiri bagi para desainer grafis freelance. Sebegitu kuatnya daya tarik tersebut sehingga bukan saja para desainer grafis dengan latar belakang akademis saja yang mengikuti kontes desain ini, namun juga menarik mereka yang tidak memiliki latar belakang akademis desain grafis atau bahkan orang yang (semula) awam sama sekali dengan dunia desain grafis. Hal seperti inilah yang terjadi di dua desa di kecamatan Salaman, kabupaten Magelang, yaitu di desa Salaman dan desa Kaliabu.

\section{Desainer Grafis Otodidak di Desa Salaman, Magelang}

Salaman adalah sebuah kecamatan di kabupaten Magelang, Jawa Tengah. Terletak 17 kilometer sebelah barat daya kota Magelang, atau 50 kilometer barat laut Yogyakarta dan hanya 5 kilometer ke arah utara dari candi Borobudur. Terdiri dari 20 kelurahan dengan pusat keramaiannya berada di kelurahan Salaman dan selebihnya adalah pedesaan. Mata pencaharian utama penduduknya adalah bercocok tanam sesuai alamnya yang cukup subur, selain itu sebagian besar menjadi pekerja kasar (tukang bangunan, sopir angkutan umum dan sebagainya) atau pegawai rendahan. Sehingga dengan begitu secara umum dapat dikatakan tingkat penghasilan secara ekonomi mereka rata-rata cenderung rendah.

Perubahan secara ekonomi terjadi ketika beberapa penduduknya mengikuti kontes desain logo melalui 99designs. Kategori desain logo lebih disukai dibanding kategori desain yang lain dari yang tersedia di 99designs karena relatif lebih mudah dikerjakan. Dipelopori oleh seorang pemuda yang bernama Elin Najar Arifin - warga kelurahan Salaman yang saat itu bekerja sebagai pemilik usaha jasa persewaan dan perbaikan PlayStation ${ }^{\circledR}$ - mencoba ikut kontes desain logo pada tahun 2010 dan mendapatkan hadiah uang sebesar US\$245 atau sekitar Rp.1.700.000,- (saat itu dengan nilai tukar Rp.7.000 per US\$). Uang sejumlah itu merupakan jumlah yang besar baginya saat itu. Namun kemenangannya tersebut diraih setelah 105 kali mencoba mengirimkan entry karya ke 99designs. Elin sendiri mendapatkan informasi mengenai kontes logo di 99designs ini dari temannya pada tahun 2008. Namun karena keterbatasan pengetahuan dan kemampuan disertai keraguan maka baru dia lakukan pada tahun 2010. Uang hasil kemenangannya yang pertama tersebut dimanfaatkan untuk menyewa bus dan mengajak teman-teman di kampungnya pergi berwisata ke pantai Baron, Gunung Kidul, Yogyakarta. Hal ini dilakukan untuk membuktikan bahwa kontes tersebut benar-benar menghasilkan uang, sekaligus mendorong semangat para pemuda di kampungnya untuk turut serta dalam kontes tersebut (Arifin, wawancara, 28-29 November 2014).

Setelah itu, beberapa orang mulai mengikuti jejak Elin untuk belajar menggunakan komputer grafis secara otodidak dan mengikuti kontes logo di 99design. Mereka adalah para pemuda yang masih kuliah, sudah bekerja atau pengangguran yang semula menjadi pelanggan jasa persewaan PlayStation $^{\circledR}$-nya. Menurut Arifin (wawancara 30 September 2015). Dorongan utama mengikuti kontes ini adalah semata-mata tertarik untuk mendapatkan uang dalam jumlah besar untuk ukuran mereka dengan cara yang relatif mudah. Arifin kemudian membentuk komunitas Salaman Designer Community yang terdiri dari warga Salaman yang tertarik menekuni desain grafis (yang kemudian untuk mengikuti kontes desain).

Jumlah warga Salaman yang mengikuti kontes logo tersebut semakin hari semakin meningkat, menurut Arifin pada tahun 2014 ada sekitar 1.500 
orang, dengan 500 orang diantaranya terhitung aktif mengirimkan karya. Klien mereka rata-rata perusahaan dari Eropa dan Australia. Menurut Arifin berdasarkan data dari pengurus situs 99designs pemasukan yang diterima oleh para desainer yang ada di kecamatan Salaman kurang lebih 45 milyar rupiah pada tahun 2013. Beberapa di antara mereka bahkan sampai meninggalkan pekerjaan lamanya untuk menekuni pekerjaan baru sebagai desainer grafis. Sementara yang lainnya masih menganggap sebagai pekerjaan sampingan (pekerjaan desain dilakukan pada malam hari).

\section{Metode Desain}

Jones (1992, 19-22) menyampaikan perihal metode desain, menurutnya ada 2 jenis metode: metode desain tradisional dan metode desain baru. Dalam metode desain tradisional dibagi menjadi dua lagi: metode craft evolution dan metode design-bydrawing. Pada metode craft evolution desainer adalah pelaku tunggal, semua hal dikerjakannya sendiri mulai dari mencari ide hingga eksekusi karya. Kalaupun ada orang lain yang membantu dalam proses ini, perannya tidaklah dominan. Dalam metode ini desainer tidak mampu menjelaskan karya mereka dengan gambar, serta tidak mampu memberi alasan yang memadai untuk keputusan desain yang mereka ambil. Karya yang mereka buat didasarkan pada percobaan yang dilakukan terus menerus selama beberapa waktu didasari dengan memperbaiki kesalahan-kesalahan yang dibuat (trial and error). Kemampuan yang mereka miliki umumnya diturunkan dari generasi sebelumnya (genetic coding) atau dipelajari dari lingkungannya. Contohnya: kemampuan para pembuat gerabah didapat dari orangtuanya atau dipelajari dari orang-orang di desanya.

Sedangkan pada metode design-by-drawing sudah terjadi pemisahan pekerjaan menjadi beberapa bagian. Maka dengan demikian memungkinkan terjadi pengerjaan pekerjaan yang lebih rumit bisa dilakukan. Dalam desain grafis misalnya, pengerjaan visualisasi sebuah company profile cetak dapat dilakukan dalam sebuah tim desain desain yang terdiri dari beberapa orang spesialis (art director, desainer grafis, fotografer, copywriter dan sebagainya) yang mana mereka dapat mengerjakan bidang spesialisasinya masing-masing baik secara berurutan maupun simultan. Pekerjaan yang mereka lakukan dipandu dengan penjelasan berupa sketsa dan briefing verbal dari art director. Maka dengan demikian pengerjaan karya yang lebih besar dan rumit lebih dimungkinkan. Hal ini sulit dilakukan pada metode craft evolution di mana pelaku hanya bekerja sendiri.

Tabel 1. Metode desain tradisional dan metode desain baru (Jones, 1992, 19 - 22)

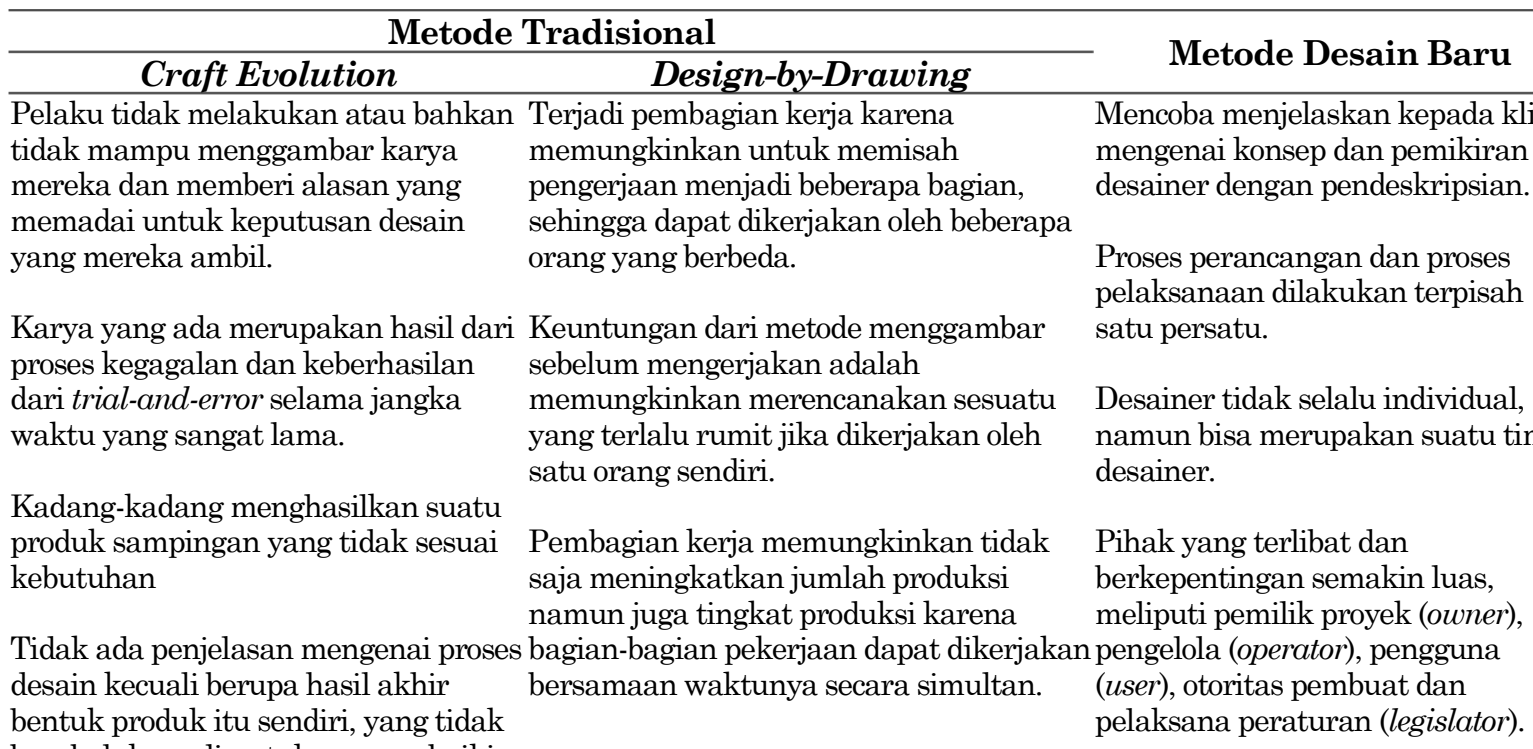

berubah kecuali untuk memperbaiki

kesalahan atau untuk memenuhi tuntutan baru.

Informasi yang tidak lengkap disimpan sebagai pola-pola yang dipelajari selama magang.

Informasi ini bisa dikatakan untuk memberikan genetic coding dari craft evolution ini. 
Pada metode desain baru beberapa hal seperti yang dilakukan pada metode design-by-drawing ditambah dengan upaya menjelaskan kepada klien mengenai konsep dan pemikiran desainer, seperti yang disampaikan oleh Paul Rand: "good design is goodwill" (Rand, dalam Amstrong (ed.), 2010, 66). Juga semakin luasnya pihak yang terlibat, seperti pemilik proyek (owner), pengelola (operator), pengguna (user), otoritas pembuat dan pelaksana peraturan (legislator). Desainer tidak selalu individual, namun bisa bekerja dalam sebuah tim. Karena proses perancangan dan proses pengerjaan dapat dilakukan secara terpisah, maka memungkinkan pekerjaan yang jauh lebih kompleks, terintegrasi dan berkelanjutan bisa dilakukan. Sebagai contoh adalah dalam pengerjaan logo sebuah perusahaan, dan logo merupakan bagian dari corporate identity. Karena corporate identity merupakan bagian dari brand, maka pekerjaan yang dilakukan tidak hanya sekedar membuat visual dari brand tersebut saja, namun juga didahului dengan pekerjaan awal misalnya menentukan brand architecture. Setelah itu pekerjaan juga berkembang dan diikuti dengan pekerjaan lanjutan seperti brand activation yang bisa terdiri dari banyak item media dan kegiatan. Media yang dimaksud adalah mulai dari media tradisional yang statis dua dimensi hingga media digital dinamis tiga dimensi. Sedangkan kegiatan yang dimaksud termasuk juga kegiatan integrated marketing communications.

\section{Penerapan Metode Desain Pembuatan Logo oleh Desainer Grafis di Desa Salaman}

Para desainer grafis kecamatan Salaman mempunyai alur kerja penciptaan desain logo sebagai berikut: (1) melihat daftar pekerjaan desain yang ditawarkan di situs 99designs.com. Seperti yang disampaikan di atas, mereka lebih menyukai jenis pengerjaan desain logo meskipun terdapat beraneka ragam pekerjaan desain lainnya. Mereka menentukan pilihan berdasarkan beberapa pertimbangan: nilai uang bayaran, tingkat kesulitan brief, jumlah entry yang telah masuk dan batas waktu yang tersedia. (2) Kemudian mereka akan mengerjakan desain tersebut berdasarkan brief tertulis yang ada di situs. Pencarian ide didasarkan pada apa yang diinginkan klien melalui brief tertulis tersebut. Arifin sendiri mengatakan bahwa $80 \%$ desain dibuat dengan mengira-ngira saja. Pengiraan ini selain berdasarkan brief, juga didasarkan dengan pengalaman yang sudah pernah dilakukan. Misalnya logo untuk perusahaan yang bergerak di bidang permesinan maka akan lebih cocok jika diberikan bentuk roda gigi atau bidang yang berhubungan dengan lingkungan hidup maka memakai bentuk pohon atau warna hijau dirasa lebih cocok. Semakin sering seorang desainer otodidak mengikuti kontes, maka kemampuan intuisi mereka semakin meningkat. Dalam hal ini, mereka belajar dari kesalahan (trial and error). Arifin juga mengatakan bahwa dalam semua penciptaan logo ini tidak pernah menyertakan konsep ataupun filosofi, untuk itu mereka tidak pernah bisa menjelaskan latar belakang penciptaannya. Semua keputusan (pemilihan bentuk, warna, simbol dan sebagainya) didasarkan perkiraan saja. (3) Setelah logo selesai dibuat kemudian dikirimkan dan berikutnya tinggal menunggu kabar hingga batas waktu yang telah ditentukan. Di antara waktu menunggu, bisa juga terjadi komunikasi antara desainer peserta kontes dengan klien melalui pesan langsung di akun 99designs atau melalui email. Semua komunikasi dilakukan dalam bahasa Inggris, sementara kemampuan bahasa Inggris desainer grafis Salaman tidak bagus. Maka mereka memanfaatkan fasilitas Google Translation untuk menterjemahkan, meskipun kadang hasil terjemahan tidak sesuai konteks permasalahan. Namun semua itu tak menjadikan halangan bagi mereka. (4) Jika dinyatakan menang, maka mereka akan menerima pengiriman uang melalui Pay Pal (Arifin, wawancara, 30 September 2015).

Cara kerja seperti yang dilakukan oleh para desainer grafis Salaman cenderung menerapkan metode craft evolution: (1) karena kemampuan mereka mengerjakan desain grafis dan penguasaan komputer grafis didapatkan secara otodidak dengan melihat secara langsung proses yang dilakukan oleh desainer grafis lain di desanya; (2) komunikasi yang dilakukan cenderung satu arah: dari klien ke desainer; (3) mereka tidak mengerti latar belakang dan maksud dari pekerjaan yang mereka lakukan, juga tidak bisa menjelaskan dan tidak pernah membuat konsep dan filosofi logo yang mereka buat; (4) logo yang berhasil menang (diterima klien) diakui sebagai hasil dari coba-coba berulang kali dengan mengingat dan memperhatikan kesalahan-kesalahan yang pernah dilakukan, seperti yang dilakukan oleh Arifin yang menang setelah mengirim entry sebanyak 105 kali.

\section{Penerapan Metode Desain oleh Desainer Grafis Profesional}

Perbedaan metode desain dapat dibandingkan dengan proses penciptaan logo Pertamina yang dilakukan oleh Landor and Associates (sebuah perusahaan konsultan brand yang didirikan tahun 1941 dengan kantor pusat di San Fransisco dan juga beberapa kantor cabang di seluruh dunia termasuk di Jakarta). Pada tahun 2005 PT. 
Pertamina menginginkan sebuah perubahan pada manajemen perusahaannya. Salah satu langkah yang dilakukan adalah dengan melakukan rebranding, yaitu kegiatan yang terintegrasi dan terencana untuk mengubah posisi brand secara internal dan eksternal (Wiryawan, 2006, 116). Untuk itu PT. Pertamina sebagai brand owner memilih Landor and Associates sebagai brand consultant mereka. Proses tahap pertama diawali dengan penunjukan resmi dan pembicaraan awal hingga penandatanganan kontrak. Setelah itu dilanjutkan dengan beberapa kali briefing dari klien.

Landor sebagai brand consultant harus melakukan brand activation dengan menyusun skenario brand architecture dengan mengetahui terlebih dahulu brand attribute. Brief dari klien dipakai sebagai materi awal untuk kelanjutan pekerjaan ini, namun data yang didapat dirasa belum cukup. Maka konsultan melakukan riset sebagai upaya menambah data. Riset ini dilakukan terhadap internal maupun eksternal klien. Hasil riset ini berupa information review, competitive benchmarking dan brand analysis. Selanjutnya data yang terkumpul digunakan sebagai dasar pencarian ide dan bangunan brand yang diinginkan (brand architecture): preliminary exploration of design directions, brand audit (current identity practices) dan data visual. Berdasarkan data tersebut dibuat beberapa alternatif bentuk logo yang kemudian dipilih setelah melalu serangkaian revisi. Setelah logo terpilih, tahap selanjutnya adalah membuat panduan (graphic standard guidelines/graphic standard manual dan penerapannya.

Jadi dalam proses ini, pembuatan logo hanya menjadi salah satu bagian saja dari seluruh pekerjaan branding. Sehingga cara kerja yang dilakukan oleh Landor and Associates dalam pembuatan logo (atau branding secara keseluruhan) lebih menerapkan metode desain desain baru. Diawali dengan (1) komunikasi dua pihak: briefing dari klien dan sebaliknya penjelasan konsep ke klien; (2) pengerjaan dilakukan oleh sebuah tim besar (metateam) yang terdiri dari beragam spesialisasi. Bahkan dalam beberapa kasus sebuah tim besar tersebut terdiri dari beberapa tim ahli yang lebih kecil (integrated marketing team atau virtual agency) termasuk diantaranya tim pemasaran, tim public relations, tim kreatif, tim produksi dan sebagainya; (3) pihak yang terlibat juga cukup luas: pemerintah sebagai pemilik BUMN PT. Pertamina yang memberikan pengawasan sekaligus legislator, PT. Pertamina sebagai brand owner, Landor and Associates sebagai pelaksana/operator dengan dibantu oleh tim-tim kecil di bawahnya; (4) mengerjakan hal yang rumit baik dalam proses maupun hasil, besar dalam kuantitas, kualitas maupun biaya (biaya pembuatan logo ini adalah US\$225.000 atau sekitar Rp. 2,55 milyar pada tahun 2005 untuk 30 aplikasi, mulai desain logo kantor pusat, stationery, stasiun pengisian bahan bakar, hingga truk pengangkut bahan bakar).

\section{Pengenalan Proses Penciptaan Logo dalam Ranah Akademik}

Dalam ranah akademik dirasa perlu agar mahasiswa bidang desain grafis mengetahui proses penciptaan logo yang baik dan benar (dalam konteks akademis), maka kepada mereka diperkenalkan prosedur yang baik dan benar pula. Sementara yang dianggap sebagai prosedur penciptaan logo yang baik dan benar ini menurut Carter (1985, 25) adalah: (1) self-study of the company, yaitu mendapatkan data seluas-luasnya mengenai klien; (2) research and evaluation of the company and its images, data dari klien saja tidak cukup maka harus ditambah dengan riset internal dan pendapat eksternal mengenai perusahaan klien tersebut; (3) definition of goals and strategies, yaitu menentukan arah tujuan dan strategi penciptaan logo; (4) development of the identity program: pengembangan bentuk kreatif; (5) implementation of the program, yaitu ketika semua bentuk kreatif yang telah diciptakan kemudian diaplikasikan ke berbagai media.

Dalam proses latihan membuat logo ini, mahasiswa dituntut bisa mengerjakan secara mandiri ataupun berkelompok. Mereka juga harus bisa menguasai keseluruh proses: mulai dari mencari data, riset, penciptaan hingga penerapan. Sedangkan evaluasi dilakukan oleh pengajar sebagai upaya mendapatkan pembelajaran. Dapat dikatakan dalam proses pembelajaran ini, metode yang diterapkan merupakan perpaduan antara craft evolution dan design-by-drawing, juga metode desain baru meskipun masih dalam taraf perkenalan.

\section{Simpulan}

Dari pemaparan di atas dapat disimpulkan beberapa hal: (1) perbedaan metode desain yang dianut antara pelaku desain grafis otodidak, profesional/korporasi dan akademis; (2) perbedaan proses kreatif yang dianut masing-masing pelaku; (3) yang mana perbedaan itu akan berpengaruh pada proses kerja, kualitas yang dihasilkan, tujuan yang dicapai, latar belakang penciptaan dan akibat sosial ekonomi yang mungkin timbul. 
Tabel 2. Tahap penciptaan logo (Carter, 1985, 25) dan penerapannya pada masing-masing level

\begin{tabular}{|c|c|c|c|}
\hline $\begin{array}{l}\text { Tahap Dasar } \\
\text { Penciptaan }\end{array}$ & Otodidak & Akademis & Profesional \\
\hline $\begin{array}{l}\text { self-study of the } \\
\text { company }\end{array}$ & $\begin{array}{l}\text { brief dari klien melalui administrator } \\
\text { situs, komunikasi dengan email } \\
\text { dengan bantuan terjemahan Google } \\
\text { Translate }\end{array}$ & $\begin{array}{l}\text { brief pengajar, } \\
\text { diberikan di kelas }\end{array}$ & brief klien \\
\hline $\begin{array}{l}\text { research and } \\
\text { evaluation of the } \\
\text { company and its } \\
\text { images }\end{array}$ & $\begin{array}{l}\text { - dilakukan dengan perkiraan saja } \\
\text { - mencari dan membandingkan } \\
\text { contoh-contoh logo yang sudah ada }\end{array}$ & $\begin{array}{l}\text { - data verbal } \\
\text { - data visual }\end{array}$ & $\begin{array}{l}\text { - information review } \\
\text { - competitive benchmarking } \\
\text { - brand analysis and strategy } \\
\text { recommendations }\end{array}$ \\
\hline $\begin{array}{l}\text { definition of goals } \\
\text { and strategies }\end{array}$ & trial and error & $\begin{array}{l}\text { konsep dan } \\
\text { filosofi logo }\end{array}$ & $\begin{array}{l}\text { - preliminary exploration of } \\
\text { design directions } \\
\text { - brand audit (current } \\
\text { identity practices) }\end{array}$ \\
\hline $\begin{array}{l}\text { development of the } \\
\text { identity program }\end{array}$ & trial and error & alternatif desain & alternatif desain \\
\hline $\begin{array}{l}\text { implementation of } \\
\text { the program }\end{array}$ & individual & individual/kelompok & tim desain \\
\hline evaluasi & evaluasi oleh desainer sendiri & evaluasi oleh pengajar & $\begin{array}{l}\text { evaluasi oleh tim desain dan } \\
\text { klien }\end{array}$ \\
\hline
\end{tabular}

Para desainer grafis Salaman lebih menerapkan metode craft evolution yang sangat sederhana dalam pelaksanaannya, sementara para profesional menerapkan prinsip yang rumit dan luas. Masing-masing tentu memiliki alasan tersendiri, para desainer grafis Salaman dengan tanpa latar belakang desain grafis secara alami mencoba melakukan proses desain yang sebaliknya bisa berlaku sangat rumit, panjang dan luas seperti yang dilakukan oleh para profesional/korporasi. Demikian pula dengan proses kreatif yang mereka jalankan masing-masing memiliki alasan yang sama dalam pelaksanaannya. Dengan demikian implikasi yang diterimapun juga sangat berbeda: perbedaan jumlah bayaran yang sangat signifikan.

Sedangkan pada ranah akademik, mahasiswa masih berada pada tataran proses penciptaan desain yang ideal dengan tanpa dibebani dengan segala hal di luar kepentingan akademis. Dari pembahasan di atas, tidak ada satupun metode yang dianggap keliru, Jones (1985, 15) bahkan mengatakan bahwa mereka yang merancang dengan metode design-by-drawing bukanlah prototipe desainer modern. Namun para perintis dari apa yang didefinisikan oleh Jones sebagai sebuah kegiatan 'merancang' adalah justru para pengrajin yang terampil. Setelah itu barulah para desainer mengambil alih saat evolusi alami menghilang.

Dengan demikian, maka dapat dikatakan bahwa para desainer grafis Salaman lebih tepat disebut sebagai pengrajin logo. Atau dengan kata lain, keberadaan mereka dapat menjadi contoh sebuah tahapan sebelum menjadi seorang desainer.
Fenomena yang terjadi pada para desainer grafis Salaman juga menimbulkan beberapa masalah di kalangan mereka: (1) harga desain yang dikendalikan oleh pasar dengan kecenderungan nilai yang rendah; (2) di kalangan para generasi muda di kecamatan Salaman muncul keengganan untuk melanjutkan studi karena lebih tertarik untuk mendapatkan uang secara mudah dengan mengikuti kontes logo; (3) meningkatnya konsumerisme di kalangan para desainer grafis Salaman karena mudahnya mendapatkan uang.

\section{Daftar Pustaka}

Amstrong, Helen (ed.) terj., Graphic Design Theory Reading from the Field, Penerbit Andi, 2010, Yogyakarta.

Arifin, Elin Najar, wawancara, 28 - 29 November 2014. , wawancara, 30 September 2015.

Carter, David E., Designing Corporate Identity Programs for Small Corporations, Art Direction Book, New York, 1985.

Jones, John Chris, Design Methods, Van Nostrand Reinhold, New York, 1992.

Landor and Associates, Pertamina Brand Strategy Recommendations, tidak dipublikasikan, materi presentasi, 2005.

Rustan, Surianto, Mendesain Logo, Gramedia Pustaka Utama, 2011, Jakarta.

Wiryawan, Mendiola B., Kamus Brand, Red \& White Publishing, Jakarta, 2008.

www.99designs.com

www.entrepreneurs-journey.com www.youtube.com 